\title{
ANALYSIS ON PROMOTION AND THE INFLUENCE OF SOCIAL MEDIA IN RESTAURANT INDUSTRY, UBUD, BALI, INDONESIA
}

\author{
Komang Ratih Tunjungsari, Putu Eka Wirawan \\ Sekolah Tinggi Pariwisata Bali Internasional (STPBI) \\ komangtunjungsari@gmail.com, wirawanputu@gmail.com
}

\begin{abstract}
The activities of promotion can be varied nowadays as the Internet technology has been developed to get information in real time. Digital promotion, such as from website and social media, is common to use to promote product and services, such as food and beverages in the restaurant including the services. The restaurant industry in Ubud has been growing since the start of the tourism in Ubud, Bali. Moreover, the promotion activities also need to be enhanced due to development of the technology. This research will discuss further the analysis of promotion and the influence of social media to influence the decision-making process of the customers to eat food in Ubud. The aim of this research was to investigate the marketing trend in promoting restaurant in Ubud. Besides, the author aimed to find the relation between the use of social media for the restaurant to influence the decision-making process of the customers to find food in Ubud. Since Ubud is a touristic area in Bali, Indonesia, the competition of the restaurant industry should have the attention of the restaurants' owners and managers. This research used descriptive analysis method to answer the research questions and collecting both secondary and primary data through literature review, observation, interview, and questionnaires. Based on our research, we found that digital promotion, such as social media marketing through social networks (Instagram, Facebook, Tripadvisor, and Website) could enhance the number of the customers in restaurants in Ubud.
\end{abstract}

Keywords: promotion, social media, restaurant, marketing 


\title{
INTRODUCTION
}

\begin{abstract}
Since tourism development in Bali blooms, the tourist accommodation and other amenities established to support the tourism and hospitality industry in Bali. Tourism is one of the productive sectors in contributing the GDRP in Bali. As it is found by Ghani et.al (2013, p. 14), that the Trade, Hotel and Restaurants counted as the largest contributors for Gross Domestic Regional Product (GDRP) about 29\% and followed by agricultural, livestock, forestry and fishery then services, finances and other sectors. Ubud is one of the sub-districts in Gianyar regency, that is assigned as one of the touristic places in Bali and very famous for its artists and its palace. Ver Berkmoes et.al. (n.d, p. 312) described Ubud as a place which offers good restaurants and café combined with workshop of local artists and provide some ancient temples, ancient villages with preserved rice fields.
\end{abstract}

According to the department of tourism in Gianyar regency, the number of visitors (domestic and foreign visitors) who visit Ubud since 2009 until 2014 shows an increase 2\% in year 2013 and 2014, such as in 2013 with total 192.215 and 2014 with total 198.468. Whereas, the number of the restaurant and café in Ubud also grows from 343 restaurants in 2013 became 355 restaurants in 2014. It can conclude that the restaurants in Ubud gain competitiveness each year to keep survive in the industry. Promotion for the enterprise, including restaurant, is essential in order to introduce the product to the customer, to increase the sale of the product and creating brand loyalty. This research aims to investigate the trend in promoting restaurant business in Ubud, related to the influence of social media as one of promising marketing channel nowadays. Moreover, the authors have two researchers question regarding promotion trend in restaurant industry in Ubud. There are "what is the promotion strategy in restaurant in Ubud?" and "How the social media influence the decision-making process to eat in Ubud?" The authors will discuss the findings below and begin with the methodology of the research. 


\section{LITERATURE REVIEW}

Promotion

According to Kotler and Armstrong (2014), marketing mix is blending the marketing tools to response the need of the market and it consists of 4 (four) P's namely, product, price, place and promotion. Dang (2014) said that to promotion is the way to increase the consumer's awareness about product, increasing the sales, and creating brand loyalty. Kotler et. al (2013) said that promotion deals with the ways of communicating the product to customers and attract them to involve the decision-making process to purchase the product. There are several promotions activities mentioned in, such as personal selling, advertising, sales promotion, collateral materials tools, direct marketing, interactive online promotion (such as web, digital media and social media), events and experiences and public relations.

Kotler et. al in Puumala and Heliste (2014) cited the term of digital marketing is the management and execution of marketing using electronic devices and digital media such as web, email, interactive TV, wireless media, mobile technology or any digital media, in conjunction with digital data from a range of databases and software applications. According to National Restaurant Association in US (2014, p.28), marketing goes digital and targeting customer should be differed by the ages. The ages 18-34 years old the group of ages who are the most receptive to social media marketing and electronic marketing.

\section{Social Media}

Puumala and Heliste (2014) describe social media and website as an ebrand to develop effectiveness and interactive communication function. Furthermore, content in social media can be channeled to persuade and inspect further information about the product leads in the website. As cited by Khanlari (2015), Kapoor defined that the social media has become a tool to influence several aspects of customer behavior including awareness, information acquisition, opinions, attitudes, purchase intention and post-purchase communication. Once again it is agreed by Palmer \& Huo in Khanlari (2015), that the development of the Web 2.0 technologies allow social network media to pop 
up into promising service tools for marketing managers in developing long-term trust for their brands.

According to Stelzner (2013), there are two major findings of the relation between the social media and marketers. First, social media is indicated important for their business agreed by the $86 \%$ of the marketers in 2013. Second, reasoning the first finding above, about $88 \%$ of marketers want to know the most effective social media to be applied as one of the strategies to engage with their customers. According to a study by Euromonitor (2014), social media and social networks are very popular in Indonesia especially Facebook with more than 63 million accounts and Twitter within 29 million active users in 2013. Other types of social media sites are Instagram and Path that gained popularity among high-income urbanites (Euro monitor, 2014).

\section{AIDA Model}

The abbreviations of AIDA consists of several words namely, attention, interaction, desire and action. According to Rofiq, Arifin and Wilopo (2012), the term of attention means a marketer should understand to attract people's attention with a powerful words or image. According to Amstrong, and Kotler (2001), there are three elements that should be fulfilled to get people's attention from the words or the picture, such as meaningful, believable and distinctive. Interests is a step when a marketer enable to create attractiveness of the information media by explaining the benefit and new innovation of the product that might see as uniqueness of the product. Desire is when the customers willing to have the products, and as a marketer already targeted the customers to create the need to buy for the customers. Action is the last step to decide the customer want to buy the product. (Rofiq, Arifin and Wilopo, 2012, p. 2-3).

\section{Restaurants Industry in Ubud}

According to Rangkuti and Wright (2014, p. 13), estimate that there are approximately 6,000 restaurants in Indonesia and Bali has around 2,600 restaurants and it is assigned to the highest food service outlets. According to Nurjaya (2011), restaurant should apply marketing strategy, such as providing the 
need of the tourists to survive in the high competition of the restaurant industry. It is also described previously in the Introduction section about the number of the visitors to Ubud increase since 2009. Moreover, the number of the restaurant also grows from 343 restaurants in 2013 into 355 restaurants in 2014. It can be concluded that there are 12 restaurants built in one year and the number of the restaurants in Ubud showing competitiveness in the restaurant industry to target the market.

\section{METHODOLOGY}

Data collection instruments or research instruments means the techniques or tools used to collect data such as observation, questionnaires, and interview (Fitzpatrick and McCarthy (2016). Firstly first, authors discuss promotion then continued into following descriptions of AIDA model applied in the promotion activities in social media. Lastly, promotion in social media activities involves the decision-making process of customers to visit the restaurant in Ubud, as it is shown the flowing chart of research framework in Figure 1 below.

This study will use both of these two types of data collection in which will be specified below. Primary data can be achieved through several methods, such as sampling procedures, exploratory methods, survey methods and observation (Pride et. al, 2012). While Saunders, Lewis and Tornhill (2012) explained types of secondary data generally for examples; documentary (text and non-text), survey (censuses, continuous or regular surveys, ad hoc surveys), and multiple sources (snapshot and longitudinal).

In addition, the authors use description to analyze the result of the questionnaires, or it is known as descriptive statistics. Descriptive statistics will include calculation of means, standard deviations, and describes the results within the percentage and narration (Burns and Bush, 2003, p.434). The questionnaires will include the respondents demographic within dimensions of marketing strategy, social media and motivation. Each variable utilizes Likert-type questions and scored on the Likert scale as shown in the Table 1 (Boone and Boone, 2012, p. 2). Author will use random sampling and already prepared filter question to plot 
the respondents who already experienced dining in restaurant in Ubud and using social media as the influencer to go to restaurant in Ubud. Furthermore, authors also use interview with the restaurant's management to answer the first research question.

Table 1. Lykert scale

\begin{tabular}{|l|c|}
\hline Statement & Scale \\
\hline Strongly agree & 5 \\
\hline Agree & 4 \\
\hline Neutral & 3 \\
\hline Disagree & 2 \\
\hline Strongly Disagree & 1 \\
\hline
\end{tabular}

\section{FINDINGS AND DISCUSSION}

According to the first research question about the analysis strategy, that held through observation and interview with the management of the restaurant in Ubud. There are 15 restaurants in Ubud (Tropical Seafood, Café Vespa, Casa Luna, Hujan Locale, Coffee Bali Harum, Toro Sushi, Warung Madu, Warung Barbeque Iga and Bebek, Urbana Restaurant, Café Bunute, Batanwaru Café, Bollero Restaurant, Sawah Indah Restaurant, D’Alas Restaurant and Kedai Ramen) interviewed previously regarding about the type of the offline promotion strategy and online promotion strategy. Among all of social media, Facebook has been the most frequently used by the restaurant to promote their product has been answered by 9 restaurants out of 15 restaurants. Besides, Instagram also gained attention from 7 restaurants since it is said the customers get easier to check the location of the restaurant and see the ambiance of the restaurant.

The promotion strategy of 6 restaurants in Ubud use website to explain their menu and products. It can be concluded the social medias achieve positive enthusiasm from the restaurant industry to help them communicate their product, such as Facebook and Instagram since these social media interestingly can share the location, pictures, give comments and another feature to enhance the two-ways communication between restaurant industry and customers. In addition, the 
restaurant industry in Ubud still applies traditional promotional strategy via offline promotion strategy such as cooperating with travel agent and guide still chosen by the restaurants' management. Besides, spreading brochures, name card and approaching the travel guide also become several ways to connect with the customers.

Table 2. Results of Demographic and the Uses of Social Media

\begin{tabular}{|c|c|c|}
\hline o. & Statements & $\begin{array}{l}\text { Number of } \\
\text { Respondents }\end{array}$ \\
\hline \multirow[t]{5}{*}{1} & \multicolumn{2}{|l|}{ Ages } \\
\hline & - $18-22$ & 15 \\
\hline & • $\quad 23-27$ & 13 \\
\hline & - $28-32$ & 6 \\
\hline & - $>37$ yo & 1 \\
\hline \multirow[t]{3}{*}{2.} & \multicolumn{2}{|l|}{ Gender } \\
\hline & - Male & 19 \\
\hline & - Female & 17 \\
\hline \multirow[t]{5}{*}{3.} & \multicolumn{2}{|c|}{ Frequently used Social media by Respondents } \\
\hline & - Twitter & 1 \\
\hline & - Path & 1 \\
\hline & - Instagram & 20 \\
\hline & - Facebook & 24 \\
\hline \multirow[t]{3}{*}{4.} & \multicolumn{2}{|c|}{ Social Media Used by the Restaurants in Ubud } \\
\hline & - Facebook & 9 \\
\hline & - Instagram & 26 \\
\hline
\end{tabular}




\begin{tabular}{|c|c|c|}
\hline & - Twitter & 1 \\
\hline \multirow[t]{3}{*}{5.} & \multicolumn{2}{|c|}{ Respondents using social media to find references in Ubud } \\
\hline & - Yes, (including TripAdvisor) & 30 \\
\hline & - No & 6 \\
\hline \multirow[t]{3}{*}{6.} & $\begin{array}{l}\text { Social Media used by the Re } \\
\text { references in Ubud }\end{array}$ & o find restauran \\
\hline & - Instagram & 31 \\
\hline & - Facebook & 5 \\
\hline
\end{tabular}

Table 2 shows us the demographics of the respondents and the utilization of the social media in promoting restaurant industry in Ubud. Mostly, the ages of the respondents are in productive ages between 18 years old until 32 years old, only one respondents' ages 37 years old. From the total 36 (thirty-six) respondents, 19 (nineteen) respondents are males and the rest 17 (seven teens) are females. The result shows the number of social media that use frequently by the respondents is Facebook about 24 respondents and 20 respondents choose Instagram, while the others choose Path and Twitter. The Table 3 below describes less than $10 \%$ of the name of restaurant in Ubud that has been visited by the respondents and own social media to communicate the restaurants' product (service and goods).

Table 3. Restaurant's with Social Media Visited by Respondents

\begin{tabular}{|l|l|}
\hline Restaurant in Ubud & $\mathrm{s}$ \\
\hline 1. Nasi Ayam Kedewatan & 2 \\
\hline 2. Babi Guling Ibu Oka & 2 \\
\hline 3. Bebek Tepi Sawah & 6 \\
\hline 4. Betelnut Ubud Bali & 1 \\
\hline
\end{tabular}




\begin{tabular}{|l|l|}
\hline 5. Café Pomegranate & 1 \\
\hline 6. Casa Luna & 1 \\
\hline 7. Copper Ubud & 1 \\
\hline 8. Clear Café Ubud & 1 \\
\hline 9. Hujan Locale & 3 \\
\hline 10. Kakiang Bakery & 2 \\
\hline 11. Locavore & 1 \\
\hline 12. Moksa & 1 \\
\hline 13. Nuris & 1 \\
\hline 14. Pizza Bagus & 4 \\
\hline 15. Pundi Restaurant & 1 \\
\hline 16. Rondji Restaurant & 2 \\
\hline 17. Pulau Kelapa & 3 \\
\hline 18. Swept Away & 2 \\
\hline 19. XL Shisa Lounge & 1 \\
\hline
\end{tabular}

About $80.6 \%$ (30 respondents) agree to use social media to find reference to restaurants in Ubud. However, about $16.7 \%$ (6 respondents) choose not to use social media in searching place to eat in Ubud and the rest choose other. Surprisingly most of them using Instagram to explore the restaurants in Ubud and it is shown by $86.1 \%$ ( 31 respondents) of the respondents while the rest $13.9 \%$ ( 5 respondents) using Facebook to discover restaurant's references in Ubud.

Answering the second research question, authors set questionnaires with 6 statements and before counting and classifying the results using a Likert scale, authors need to measure the interval of each score from one (1) the lowest until (5) the highest scores as it is shown below.

Score Maximum : (number of the respondents) $x$ highest score $: 36$ x $5=$ 180 
Score Minimum : (number of the respondents) $\mathrm{x}$ lowest score : $36 \mathrm{x}$ $1=36$

The interval $=\quad$ Score Maximum - Score Minimum

$$
\underline{180-36}=28.8
$$

From the interval, then the authors divide the interval of the score as shown below in Table 4. There are 6 (six) statements based on the AIDA model according to the relevancy of social media within the promotions definition. The result of the interval accounted 28.8 in each score of the note.

Table 4. Interval of the score

\begin{tabular}{|c|c|}
\hline \multicolumn{1}{|c|}{ Note } & Scor \\
& \multicolumn{2}{|c|}{151.} \\
\hline Sgree & $2-180$ \\
\hline Strongly & 122. \\
\hline Agree & $4-150.2$ \\
\hline Neutral & 93.6 \\
& -121.4 \\
\hline
\end{tabular}




\begin{tabular}{|c|c|}
\hline Disagree & \multicolumn{2}{|c|}{64.8} \\
& -92.6 \\
\hline Strongly & \multicolumn{2}{|c|}{$36-$} \\
Disagree & 63.8 \\
\hline
\end{tabular}

It is shown in Table 5, most of the dimension of AIDA model ranged between the score classification in 'agree'. For example, the first statement about attention says social media give information about the product of the restaurants in Ubud with the total score 135. It means the first statement can be included in the interval of the agreement. Moreover, the second dimension of interest in AIDA model, which are presented in the second, third and fourth question also shows the score of the interval ranged from 135, 133 and 136. The third dimension, interest, exposed in the fifth question and the interval scored in 134 . Last dimension in AIDA model, action, shown in the sixth question about the decision-making process and the influence of social media to buy and eat food in the restaurant in Ubud, ranged in interval 126 and still classified as agreeing with the statement.

Nowadays, social media and marketing can be combined and create the term of Social Media Marketing (SMM). Neti (2011) believed that, SMM could help to grow the customer's satisfaction through using social media as the interactive session within the customers by listening to their feedback whilst identifying the customers. Through SMM, the business organization could also identify the peer of a group that will be targeted as it could be adjusted.

It also agreed by Weinberg (2009) who defines SMM as a process that empowers individuals to promote their websites, products, or services through online social channels and to communicate with and engage into global community that might not have been provided by the traditional marketing channels. As cited in Hunt (2009), the vital aspect of SMM is to communicate with a community. The purposes of SMM as a Public Relations (PR) and describes SMM as a practice of facilitating dialogue and sharing content between 
companies, influencers, prospects and customers, using different kinds of online platforms. (Marketing Sherpa, 2009)

Table 5. The results of AIDA Statements

\begin{tabular}{|c|c|}
\hline Statements & TOTA \\
\hline $\begin{array}{l}\text { 1. Social media give information about the product of the } \\
\text { restaurant in Ubud }\end{array}$ & 135 \\
\hline $\begin{array}{l}\text { 2. The pictures shown in the restaurant's social media } \\
\text { account are attractive }\end{array}$ & 136 \\
\hline 3. Social Media could create image of the restaurant's brand \\
\hline $\begin{array}{l}\text { 4. Social media account makes you easier to know } \\
\text { promotion information from the restaurant }\end{array}$ \\
\hline $\begin{array}{l}\text { 5. The social media account could influence your appetite } \\
\text { 6. Social Media influence your decision-making process to }\end{array}$ \\
\hline
\end{tabular}

Moreover, as written in Lee, Xiong and $\mathrm{Hu}$ (2012) Ellison believe that Facebook is a valuable platform to be used with highly interactive capabilities. According to Pellikka (2014) Instagram is a social media platform aimed towards, sharing pictures and short video clips within the locations as well. The pictures or video clips could be liked, commented and mentioned or popularized through \#hashtag. Similarly to other social media platforms, the content uploaded by the SMM team can be shared to another service such as Facebook and Twitter. Through hashtag, it is very easy to find similar information from it is written in hashtag.

\section{CONCLUSION AND SUGGESTION}

Marketing strategy for restaurant industry can be explained in two ways, offline and online marketing. One of the aspects of marketing mix including promotion has taken vital role to communicate the product of the restaurant to the customers. As the type of the promotion has developed into more digital, such as 
social media that people can share the picture, location, comments and short video in the real time. It is should be considered for the restaurant industry to maintain their digital promotion to attract customers until influence their decision-making process to buy the product of the restaurant through AIDA model and optimizing the use of social media. Supporting by the growing restaurant industry in Ubud, it is necessary for the restaurant management to keep their promotion online. The awareness of social media marketing by the restaurants in Ubud could create competitiveness among the restaurants in Bali.

Since every social network (Facebook, Instagram, Twitter, Path and Tripadvisor) has their own ways to promote, the restaurants' manager or the sales and marketing manager of the restaurant should utilize these social networks according to their own rule to obtain the targeted market. Segmenting the job description of each social network might be necessary to apply when the restaurant needs more network to promote the restaurants. For example in Facebook, the restaurant can create the fan page to communicate their new menu or their happy hour's promo. The restaurants also can be promoted by differing their target in the sponsored publicity in Facebook. Whereas Instagram, can attract beautiful pictures and attached the location and hashtag to make the most recognized worldwide.

\section{REFERENCES}

[1] Armstrong, G. and Kotler, P. (2001). Prinsip-prinsip pemasaran jilid 1 (Edisi Kedelapan). Jakarta: Erlangga.

[2] Berg, B. L. (2001). Qualitative research methods for the social sciences. United States: Allyn \& Bacon.

[3] Boone, H. N and Boone, D.A. (2012). Analyzing likert data. Journal of Extension 50 (2), 2TOT2, 1-5. 
[4] Burns, A.C and Bush, R.F. (2003). Marketing research applications (4 $4^{\text {th }}$ ed.). Hall: Pearson Prentice.

[5] Dang, T. (2014). The success of applying marketing mix 4s in vietnamese dairy industry: vinamilk - a typical case. Degree Thesis. Arcada

[6] Euromonitor. (2014). Consumer lifestyle in Indonesia. Passport International.

[7] Fitzpatrick, J. J. And Mccarthy, G. (2016). Nursing Concept Analysis: Applications to research and practice. New York: Springer.

[8] Ghani, J., Mawardi, I., Rashdi, A., Van Garderen, G., Weisenberger, T. (2013). Microeconomics of Competitiveness: Bali Taste Paradise. Retrieved from http://www.isc.hbs.edu/resources/courses/moc-course-atharvard/Documents/pdf/student-projects/Indonesia_Tourism_2013.pdf

[9] Hunt, T. (2009). The whuffie factor: using the power of social networks to build your business. New York: Crown Business.

[10] Khanlari, A. (2015). Strategic customer relationship management in the age of social media. USA : IGI Global.

[11] Kotler, P. and Armstrong, G. (2014). Principles of Marketing: global edition (15th ed.). Pearson Education Limited.

[12] Kotler, P., Armstrong, G., Harris, L.C. \& Piercy, N. (2013). Principles of marketing (6th European ed.). Harlow, England: Pearson Education Limited. 
[13] Lee, W., Xiong, L., Hu, C. (2012). The effect of Facebook users' arousal and valenve on intention to go to festival: Applying an extension of the technology acceptance model. International Journal of Hospitality Management, 3 (2012), 819-827.

[14] Marketing Sherpa (2009). Social media marketing \& PR: benchmark guide. $\quad$ Retrieved from http://www.marketingsherpa.com/exs/SocialMM09excerpt.pdf

[15] Neti, S. (2011). Social Media and Its role in Marketing. International Journal of Enterprise Computing and Business Systems, 1 (2), 1-15.

[16] Nurjaya, I.W. (2011). Persepsi wisatawan mancanegara terhadap potensi pariwisata di Kelurahan Ubud, Kabupaten Gianyar. Thesis. Universitas Udayana.

[17] Pellikka, H. (2014). Gamification in social media. Master Thesis. University of Oulu, Oulu. 20 April 2014.

[18] Puumala, T. and Heliste, P. (2014). Social media marketing communications plan for a B2B company. Degree in International Business. Oulu University of Applied Sciences.

[19] Rofiq, A., Arifin, Z, and Wilopo. (2012) . Pengaruh penerapan AIDA (Attention, Interest, Desire, Action) terhadap keputusan pembelian. Universitas Brawijaya

[20] Stelzner, M.A. (2013). How marketers are using social media to grow their business. Retrieved from http://www.socialmediaexaminer.com/SocialMediaMarketingIndustryReport2 013.pdf accessed, 03 November 2015.

[21] Saunders, M., Lewis, P., and Thornhill, A. (2012). Research methods for business students ( $6^{\text {th }}$ ed). England: Pearson. 
[22] Snape, D. and Spencer, L. (2003). The foundations of qualitative research, in RITCHIE, Jane and LEWIS, Jane (eds). Qualitative Research Practice: a guide for social science researchers and students. Sage Publications, Ltd. London, 1-23.

[23] Veal, A. J. (2011). Research methods for leisure and tourism: A practical guide ( $4^{\text {th }}$ ed). Prentice Hall: England.

[24] Ver Berkmoes, R. et.al, (no date). Indonésie (4th ed.). Lonely Planet. Retrieved from https://wisuda.unud.ac.id/pdf/1012025032-2-bab\%20i.pdf

[25] Weinberg, T. (2009). The new community rules: marketing on the social web. Sebastopol, CA: O’Reilly Media, Inc. 